Sains Malaysiana 48(7)(2019): 1557-1563

http://dx.doi.org/10.17576/jsm-2019-4807-25

\title{
Outlier Detection in Multiple Circular Regression Model using DFFITC Statistic
}

(Pengesanan Nilai Tersisih dalam Model Regresi Berkeliling Berganda menggunakan Statistik DFFITC)

\author{
NAJla Ahmed AlKasadi, SaFwati Ibrahim*, Ali H. M. AbuZAid, Mohd IrWAN Yusoff, \\ HASHIBAH HAMID, LEOW WAI ZHE \& AMELIA BT ABD RAZAK
}

\begin{abstract}
This paper presents the identification of outliers in multiple circular regression model (MCRM), where the model studies the relationship between two or more circular variables. To date, most of the published papers concentrating on detecting outliers in circular samples and simple circular regression model with one independent circular variable. However, no related studies have been found for more than one independent circular variable. The existence of outliers could alert the sign and change the magnitude of regression coefficients and may lead to inaccurate model development and wrong prediction. Hence, the intention is to develop an outlier detection procedure using DFFITS statistic for circular case. This method has been successfully used in multiple linear regression model. Therefore, the DFFITc statistic for circular variable has been derived. The corresponding critical values and the performance of the procedure are studied via simulations. The results of simulation studies show that the proposed statistic perform well in detecting outliers in MCRM using DFFITc statistic. The proposed statistic was applied to a real data for illustration purposes.
\end{abstract}

Keywords: Circular data; circular regression model; DFFITS; outlier

ABSTRAK

Kertas ini membentangkan pengesanan nilai tersisih dalam model regresi berkeliling berganda (MCRM) dengan model tersebut mengkaji hubungan antara dua atau lebih pemboleh ubah berkeliling. Sehingga kini, kebanyakan kertas yang diterbitkan menumpukan ke atas pengesanan nilai tersisih dalam sampel berkeliling dan model regresi berkeliling ringkas untuk satu pemboleh ubah tak bersandar. Walau bagaimanapun, tiada kajian yang berkaitan telah dijumpai untuk lebih daripada satu pemboleh ubah berkeliling tak bersandar. Kewujudan nilai tersisih dapat memberi isyarat tanda dan mengubah perubahan magnitud pekali regresi dan mungkin menyebabkan pembangunan model yang tidak tepat dan ramalan yang salah. Oleh itu, objektif kajian adalah untuk membangunkan kaedah pengesanan nilai tersisih menggunakan statistik DFFITS untuk kes berkeliling. Kaedah ini telah berjaya digunakan dalam model regresi linear berganda. Oleh itu, statistik DFFITc untuk pemboleh ubah berkeliling telah diterbitkan. Nilai genting sepadan dan prestasi prosedur dikaji melalui simulasi. Hasil kajian simulasi menunjukkan bahawa statistik yang dicadangkan menunjukkan prestasi yang baik dalam mengesan nilai tersisih di dalam MCRM menggunakan statistik DFFITc. Statistik yang dicadangkan diaplikasikan kepada data sebenar untuk tujuan ilustrasi.

Kata kunci: Data berkeliling; DFFITs; model regresi berkeliling; nilai tersisih

\section{INTRODUCTION}

The multiple circular regression model is used to study the relationship between two or more circular variables as proposed by Ibrahim (2013). The model has interesting properties which are very close resemblance to that of the multiple linear regression models, including the sensitivity to the existence of outliers. Circular statistics are used in many different fields such as physics, medicine, oceanography, meteorology and biology. One of the most common problems in any statistical analysis is the existence of some unexpected observations, it is called outliers. Some studies have shown that outliers affect the performance of standard statistical methodology in modeling, diagnostic, and forecasting processes. The existence of outliers affects most of the statistical properties of the model (Abuzaid et al. 2009; Beckman \& Cook 1983; Peña 1990).
The identification of outliers in circular data received great interest especially on the use the new methods, which were extended from the linear regression model to the simple circular regression model (Abuzaid et al. 2013, 2011; Hussin et al. 2013; Ibrahim et al. 2013; Rambli et al. 2015, 2012). Recently, Alkasadi et al. (2018, 2016) considered the problem of outliers in multiple circular regression model. There are few published works on the problem of outlier detection in multiple linear regression by using the DFFITS statistic, such as in Ampanthong \& Suwattee (2009), Belsley et al. (1980), Wong (1992) and Zakaria et al. (2014).

In the literature, the methods of outliers' detection in linear case has been successfully used DFFITS statistic. However, there is no published work related to the detection of outliers on circular case using DFFITS statistic. 
In this paper, we will extend the statistic of DFFITS to detect outliers in multiple circular regression models (MCRM).

This article is organized as follows: First, we review the multiple circular regression model and explains the estimation of model parameters via the least squares method. Next, we demonstrate the proposed of DFFITC statistic for the MCRM. After that, we obtains the cut-off points and investigates the performance of the proposed statistic. Lastly, we discusses the detection of outliers in multivariate eye data for illustration purpose.

\section{THE MULTIPLE CIRCULAR REGRESSION MODEL (MCRM)}

The MCRM which was proposed by Ibrahim (2013) study the relationship between a dependent circular variable and one or more independent circular variables. In this paper, we only focuses on two independent circular variables; $\boldsymbol{U}_{1}$, and $\boldsymbol{U}_{2}$ with the dependent circular variable $\boldsymbol{V}$. The MCRM in terms of the conditional expectation, $e^{i v}$ is given by,

$$
E\left(e^{i v} \mid u_{1}, u_{2}\right)=\rho\left(u_{1}, u_{2}\right) e^{i, \mu\left(u_{1}, u_{2}\right)}=g_{1}\left(u_{1}, u_{2}\right)+i g_{2}\left(u_{1}, u_{2}\right)
$$

where $\mu\left(u_{1}, u_{2}\right)$ is the conditional mean direction of $v$ given $u_{1}$ and $u_{2}$ and $\rho\left(u_{1}, u_{2}\right)$ is the conditional concentration towards $\mu\left(u_{1}, u_{2}\right)$.

The parameters $\mu\left(u_{1}, u_{2}\right)$ may be estimated such that

$$
\mu\left(u_{1}, u_{2}\right)=\hat{v}=\arctan \frac{g_{2}\left(u_{1}, u_{2}\right)}{g_{1}\left(u_{1}, u_{2}\right)}\left\{\begin{array}{cc}
\tan ^{-1} \frac{g_{2}\left(u_{1}, u_{2}\right)}{g_{1}\left(u_{1}, u_{2}\right)} & \text { if } g_{1}\left(u_{1}, u_{2}\right) \geq 0 \\
\pi+\tan ^{-1} \frac{g_{2}\left(u_{1}, u_{2}\right)}{g_{1}\left(u_{1}, u_{2}\right)} & \text { if } g_{1}\left(u_{1}, u_{2}\right) \leq 0 \\
\text { undefined } & \text { if } g_{1}\left(u_{1}, u_{2}\right)=g_{2}\left(u_{1}, u_{2}\right)=0
\end{array}\right.
$$

The values of $g_{1}\left(u_{1}, u_{2}\right)$ and $g_{2}\left(u_{1}, u_{2}\right)$ may be estimated using the following trigonometric polynomials of a suitable degree $(m)$ as,

$$
\begin{aligned}
& g_{1}\left(u_{1}, u_{2}\right) \approx \sum_{k, \ell=0}^{m} \gamma_{k \ell}\left[\begin{array}{l}
A_{k \ell} \cos k u_{1} \cos \ell u_{2}+B_{k \ell} \cos k u_{1} \sin \ell u_{2} \\
+C_{k \ell} \sin k u_{1} \cos \ell u_{2}+D_{k \ell} \sin k u_{1} \sin \ell u_{2}
\end{array}\right] \\
& g_{2}\left(u_{1}, u_{2}\right) \approx \sum_{k, \ell=0}^{m} \gamma_{k \ell}\left[\begin{array}{l}
E_{k \ell} \cos k u_{1} \cos \ell u_{2}+F_{k \ell} \cos k u_{1} \sin \ell u_{2} \\
+G_{k \ell} \sin k u_{1} \cos \ell u_{2}+H_{k \ell} \sin k u_{1} \sin \ell u_{2}
\end{array}\right]
\end{aligned}
$$

$$
\text { where } \gamma_{k l}=\left\{\begin{aligned}
\frac{1}{4} & \text { for } \quad k=l=0 \\
\frac{1}{2} & \text { for } k>0, l=0 \text { and for } k=0, l>0 \\
1 & \text { for } \quad k>0, l>0
\end{aligned}\right.
$$

Thus, and based on (3), there are two models as follow;

$$
\begin{aligned}
& V_{1 j}=\cos v_{j}=\sum_{k, l=0}^{m}\left(\begin{array}{c}
A_{k \ell} \cos k u_{1} \cos \ell u_{2}+B_{k \ell} \cos k u_{1} \sin \ell u_{2} \\
+C_{k \ell} \sin k u_{1} \cos \ell u_{2}+D_{k \ell} \sin k u_{1} \sin \ell u_{2}
\end{array}\right)+\varepsilon_{1 j} \\
& V_{2 j}=\sin v_{j}=\sum_{k, l=0}^{m}\left(\begin{array}{c}
E_{k \ell} \cos k u_{1} \cos \ell u_{2}+F_{k \ell} \cos k u_{1} \sin \ell u_{2} \\
+G_{k \ell} \sin k u_{1} \cos \ell u_{2}+H_{k \ell} \sin k u_{1} \sin \ell u_{2}
\end{array}\right)+\varepsilon_{2 j}
\end{aligned}
$$

for $i=1, \ldots, n$ and $\varepsilon=\left(\varepsilon_{1}, \varepsilon_{2}\right)$ is the vector of random errors following a bivariate normal distribution with mean $\boldsymbol{O}$ and dispersion matrix $\Sigma$. The parameters $A_{k l}, B_{k l}, C_{k l}, D_{k l}, E_{k l}$, $F_{k l}, G_{k l}$ and $H_{k l}$, where $k l=0,1, \ldots, m$, the standard errors as well as the dispersion matrix $\Sigma$ can then be estimated using generalized least squares method.

We estimate the parameters of MCRM by using the least squares method. For a random sample of size $n$ from (4), in order to ensure identifiability, it was assumed that $B_{00}=C_{00}=D_{00}=F_{00}=G_{00}=H_{00}=0$.

Subsequently, $\boldsymbol{V}^{(1)}$ and $\boldsymbol{V}^{(2)}$ were written in the matrix form as

$$
\begin{aligned}
& \boldsymbol{V}^{(1)}=\boldsymbol{U} \boldsymbol{\lambda}^{(1)}+\boldsymbol{\varepsilon}^{(1)} \\
& \boldsymbol{V}^{(2)}=\boldsymbol{U} \boldsymbol{\lambda}^{(2)}+\boldsymbol{\varepsilon}^{(2)} .
\end{aligned}
$$

Thus, the least squares estimation turns out to be given by

$$
\begin{aligned}
& \hat{\lambda}^{(1)}=\left(\boldsymbol{U}^{\prime} \boldsymbol{U}\right)^{-1} \boldsymbol{U}^{\prime} \boldsymbol{V}^{(1)} \\
& \hat{\lambda}^{(2)}=\left(\boldsymbol{U}^{\prime} \boldsymbol{U}\right)^{-1} \boldsymbol{U}^{\prime} \boldsymbol{V}^{(2)} .
\end{aligned}
$$

where $\boldsymbol{U}$ is the matrix of the combination of cosine and sine functions, such that

$$
\underset{n \times(4 m+1)}{\boldsymbol{U}}=\left[\begin{array}{ccccc}
\underset{n \times 1}{1} & \underset{n \times m}{\boldsymbol{C C}} & \underset{n \times m}{\boldsymbol{C S}} & \underset{n \times m}{S C} & \underset{n \times m}{S S}
\end{array}\right]
$$

The covariance matrix of the residuals, $\Sigma$ is estimated as follow

$$
\hat{\Sigma}=[n-2(4 m+1)]^{-1} R_{0}
$$

where $R_{0}=\left(R_{0}(p, q)\right)_{p, q=1,2}$ and $R_{0}(p, q)=\boldsymbol{V}^{(p)^{\prime}} \boldsymbol{V}^{(q)}-\boldsymbol{V}^{(p)^{\prime}}$ $\boldsymbol{U}\left(\boldsymbol{U}^{\prime} \boldsymbol{U}\right)^{-1} \boldsymbol{U}^{\prime} \boldsymbol{V}^{(q)}$, is an unbiased estimation of $\boldsymbol{\Sigma}$ and $m$ is a suitable degree (Ibrahim 2013).

\section{DFFITC STATISTIC OF MCRM}

One of the methods to identify outliers in linear regression is DFFITS statistic which measures the effect of deleting a given observation on the predicted or fitted values. Belsley et al. (1980) proposed DFFITS statistic which is defined as, 


$$
\operatorname{DFFITS}_{i}=\frac{\hat{y}_{i}-\hat{y}_{i(-i)}}{\sqrt{S_{(-i)}^{2} h_{i i}}}
$$

for , $i=1,2, \ldots, n$, where $\hat{y}_{i}$ and $\hat{y}_{i(-i)}$ are the prediction for point $i$ with and without point $i$ included in the regression, respectively. $S_{(-i)}$ denotes the standard error estimated without the point $i$ and $h_{\mathrm{ii}}$ is the leverage of the point. The DFFITS statistic is large if the data point has high leverage which leads $h_{\mathrm{ii}}$ to be close to unity. Belsley et al. (1980) suggested that any observation for which $\mid$ DFFITS $_{i} \mid>2 \sqrt{k / n}$ indicates outliers, where $k$ is the number of predictor variables and $n$ is the sample size (Cousineau \& Chartier 2010; Rousseeuw \& Leroy 2005). This section extends the DFFITS to identify possible outliers in the MCRM.

An outlier detection procedure for the MCRM is developed using row deletion approach. In regression model, it is expected that the parameter estimates, variance of residuals, covariance matrix as well as the standard errors will be affected if an outlier exists in the data. In particular, we look at the effect of removing an observation on the fitted values, at the same time it will effects on standard error estimated and covariance matrix of residuals.

The proposed of DFFITc statistic is given by,

$$
\operatorname{DFFITC}_{j i}=\frac{\hat{\boldsymbol{V}}_{j}-\hat{\boldsymbol{V}}_{j(-i)}}{\sqrt{S_{(-i)}^{2} h_{j j}}} \quad(\bmod 2 \pi)
$$

where $\hat{\boldsymbol{V}}_{j}$ denotes the prediction from the full regression model for the $i$ th observation, meanwhile $\hat{V}_{j(-i)}$ denotes the prediction when the $i$ th observation is deleted. $S_{(-i)}$ denotes the standard error which is estimated without the point $i$ while $h_{j j}$ is the $j$ th diagonal element of $\left(\boldsymbol{U}^{\prime} \boldsymbol{U}\right)^{-1}$ where the matrix $\boldsymbol{U}$ is the combination of cosine and sine functions as given in Equation (7). The $i$ th observation is identified as an outlier if the value of DFFITC exceeds the pre-specified cutoff point, which will be obtained in the following section.

\section{CRITICAL VALUES OF DFFITC STATISTIC}

A simulation study is carried out to obtain the cut-off points of the DFFITC statistic for different values of different sample sizes $n=20,40,60,80,100$ and standard deviations and . For $m=1$, ten coefficients are to be estimated; namely, $A_{0}, A_{1}, B_{1}, C_{1}, D_{1}, E_{0}, E_{1}, F_{1}, G_{1}$ and $H_{1}$. For simplicity, we set the true values of $A_{0}$ and $E_{0}$ of the MCRM of order $m=1$ to be zero, while the other eight parameters, namely, $A_{1}, B_{1}, C_{1}, D_{1}, E_{1}, F_{l}, G_{1}$ and $H_{1}$ are obtained by using the standard additive trigonometric polynomial equations cos $\left(a+u_{1}+u_{2}\right)$ and $\sin \left(a+u_{1}+u_{2}\right)$. Then, these functions are expanded using standard additive trigonometric function. For example, when $a=2$, we have $\cos \left(2+u_{1}+u_{2}\right)=0.4161$ $\cos u_{1} \cos u_{2}-0.9093 \cos u_{1} \sin u_{2}-0.9093 \sin u_{1} \cos u_{2}$ $+0.4161 \sin u_{1} \cos u_{2}$ and $\sin \left(2+u_{1}+u_{2}\right)=0.9093 \cos u_{1}$ $\cos u_{2}-0.4161 \cos u_{1} \sin u_{2}-0.4161 \sin u_{1} \cos u_{2}-0.9093$ $\sin u_{1} \sin u_{2}$. Then, by comparing with (4), the true values of $A_{1}, B_{1}, C_{1}, D_{1}, E_{1}, F_{1}, G_{1}$ and $H_{1}$ to be $0.4161,-0.9093$, $-0.9093,0.4161,0.9093,-0.4161,-0.4161$ and -0.9093 , respectively, with $A_{0}$ and $E_{0}$ being zero. Similarly, we can also get different sets of true values by choosing different values of $a$ (Ibrahim 2013).

Then, the $10 \%, 5 \%$ and $1 \%$ upper percentiles of the maximum values of DFFITC are obtained. The full procedures to obtain the critical values are summarized as follows;

1. Generate the independent variables $\boldsymbol{U}_{1}$ and $\boldsymbol{U}_{2}$ of size $n$ from von Mises distribution with mean $\pi$ and concentration parameters 3 and $2(V M(\pi, 3)$ and $V M$ $(\pi, 2))$, respectively.

2. Generate $\varepsilon_{1}$ and $\varepsilon_{2}$ of size $n$ from $N\left(\left(\begin{array}{l}0 \\ 0\end{array}\right),\left(\begin{array}{ll}\sigma_{1} & 0 \\ 0 & \sigma_{2}\end{array}\right)\right)$. For a fixed $a=2$, obtain the true values of $\lambda=A_{0}, A_{1}, B_{1}$, $C_{1}, D_{1}, E_{0}, E_{1}, F_{1}, G_{1}$ and $H_{1}$. Here, let the true values of $A_{0}$ and $E_{0}$ to be zero. Then, calculate $\boldsymbol{V}_{1 j}$ and $\boldsymbol{V}_{2 j}$, $j=1, \ldots, n$, using (4) .

3. Obtain the circular variable $v_{j}=\arctan \left(\frac{\boldsymbol{V}_{2 j}}{\boldsymbol{V}_{1 j}}\right), j=1, \ldots, n$ using (2).

4. Fit the generated circular data using the MCRM to give the parameter estimates of $\hat{\lambda}=\hat{A}_{0}, \hat{A}_{1}, \hat{B}_{1}, \hat{C}_{1}, \hat{D}_{1}, \hat{E}_{0}, \hat{E}_{1}$, $\hat{F}_{1}, \hat{G}_{1}$ and $\hat{H}_{1}$ as given in (6).

5. Exclude the $i$ th row from the generated circular data, where $i=1, \ldots, n$. For each $i$, repeat steps (4) for the reduced data set to obtain $\hat{\lambda}_{j(-i)}$.

6. Compute DFFITC $_{j i}$ for each $i$ from (10).

7. Specify the maximum value of $D F F I T c_{j i}$.

The process is repeated 2000 times for each combination of sample size $n$ and standard deviation $\left(\sigma_{1}, \sigma_{2}\right)$ $=(0.03,0.03),(0.05,0.05),(0.1,0.1)$ and $(0.3,0.3)$.

Table 1 represents the critical values at 5\% upper percentiles for different sample size $n$ and standard deviation $\left(\sigma_{1}, \sigma_{2}\right)$ at $a=2$. The others critical values can be obtained from the authors upon request. The results show that, for a fixed $\sigma_{1}$ and $\sigma_{2} \geq \sigma_{1}$, the cut-off point increases as $\sigma_{1}$ gets larger. A similar pattern is observed for a fixed $\sigma_{2}$ where $\sigma_{1} \geq \sigma_{2}$. This is because the residual error values will be small and fluctuated around the unit circle. Thus, for low leverage points, the values of DFFITc are expected to be small, whereas as the leverage goes to 1 the distribution of the DFFITC value enlarges infinitely. On the other hand, the cut-off points have a decreasing function of the sample size $n$. 
TABLE 1. Cut-off points at 5\% upper percentiles of DFFITc statistic at $a=2$

\begin{tabular}{|c|c|c|c|c|c|c|}
\hline$n$ & $\sigma_{1}$ & 0.03 & 0.05 & $\begin{array}{c}\sigma_{2} \\
0.08\end{array}$ & 0.1 & 0.3 \\
\hline \multirow{5}{*}{20} & 0.03 & 0.0761 & 0.0809 & 0.0835 & 0.0850 & 0.0888 \\
\hline & 0.05 & 0.0707 & 0.0738 & 0.0780 & 0.0782 & 0.0799 \\
\hline & 0.08 & 0.0795 & 0.0815 & 0.0817 & 0.0827 & 0.0864 \\
\hline & 0.1 & 0.0804 & 0.0822 & 0.0848 & 0.0845 & 0.0859 \\
\hline & 0.3 & 0.0720 & 0.0722 & 0.0723 & 0.0750 & 0.0765 \\
\hline \multirow{5}{*}{40} & 0.03 & 0.0475 & 0.0490 & 0.0552 & 0.0579 & 0.0695 \\
\hline & 0.05 & 0.0489 & 0.0500 & 0.0531 & 0.0560 & 0.0704 \\
\hline & 0.08 & 0.0510 & 0.0521 & 0.0522 & 0.0535 & 0.0704 \\
\hline & 0.1 & 0.0536 & 0.0536 & 0.0539 & 0.0543 & 0.0690 \\
\hline & 0.3 & 0.0668 & 0.0677 & 0.0679 & 0.0698 & 0.0693 \\
\hline \multirow{5}{*}{60} & 0.03 & 0.0352 & 0.0381 & 0.0426 & 0.0445 & 0.0550 \\
\hline & 0.05 & 0.0367 & 0.0370 & 0.0395 & 0.0421 & 0.0540 \\
\hline & 0.08 & 0.0388 & 0.0391 & 0.0391 & 0.0411 & 0.0538 \\
\hline & 0.1 & 0.0389 & 0.0398 & 0.0403 & 0.0404 & 0.0525 \\
\hline & 0.3 & 0.0487 & 0.0499 & 0.0500 & 0.0511 & 0.0514 \\
\hline \multirow{5}{*}{80} & 0.03 & 0.0275 & 0.0318 & 0.0347 & 0.0357 & 0.0516 \\
\hline & 0.05 & 0.0289 & 0.0291 & 0.0328 & 0.0340 & 0.0513 \\
\hline & 0.08 & 0.0310 & 0.0314 & 0.0316 & 0.0321 & 0.0502 \\
\hline & 0.1 & 0.0305 & 0.0313 & 0.0313 & 0.0318 & 0.0486 \\
\hline & 0.3 & 0.0411 & 0.0419 & 0.0426 & 0.0431 & 0.0445 \\
\hline \multirow{5}{*}{100} & 0.03 & 0.0246 & 0.0273 & 0.0296 & 0.0312 & 0.0418 \\
\hline & 0.05 & 0.0259 & 0.0263 & 0.0276 & 0.0276 & 0.0416 \\
\hline & 0.08 & 0.0263 & 0.0266 & 0.0272 & 0.0284 & 0.0411 \\
\hline & 0.1 & 0.0250 & 0.0253 & 0.0282 & 0.0293 & 0.0418 \\
\hline & 0.3 & 0.0298 & 0.0323 & 0.0365 & 0.0394 & 0.0421 \\
\hline
\end{tabular}

\section{THE PERFORMANCE OF DFFITC STATISTIC}

A simulation study is carried out to investigate the performance of DFFITC statistic for detecting outliers in the MCRM. Five different sample size are considered, $n=20$, $40,60,80$ and 100 with different value of $\left(\sigma_{1}, \sigma_{2}\right)=(0.03$, $0.03),(0.05,0.05),(0.1,0.1)$ and $(0.3,0.3)$. The observation at position $d$, say $v_{d}$, is contaminated as follows:

$$
v_{d}^{*}=v_{d}+\tau \pi \quad(\bmod 2 \pi)
$$

where $v_{d}^{*}$ is the response value after contamination and $\tau$ is the degree of contamination in the range $0 \leq \tau \leq 1$. The generated data of $\boldsymbol{U}_{1}, \boldsymbol{U}_{2}$ and $\boldsymbol{V}$ are then fitted to obtain the parameter estimates of $\hat{A}_{0}, \hat{A}_{1}, \hat{B}_{1}, \hat{C}_{1}, \hat{D}_{1}, \hat{E}_{0}, \hat{E}_{1}, \hat{F}_{1}, \hat{G}_{1}$ and $\hat{H}_{1}$. Consequently, exclude the $i$ th row from the sample, for $i=1, \ldots, n$ and refit the remaining data using (6). Then, the DFFITc $c_{j i}$ is calculated. If the values of DFFITc is maximum and greater than the corresponding cut-off point, then the procedure has correctly detecte the outlier in the data. The process is carried out 5000 times. The power of performance of the procedure is then examined by computing the percentage of the correct detection of the contamination observation at point $d$.

Figure 1 illustrates the power of performance of DFFITC statistic for $n=100$ and four values of standard deviation $\left(\sigma_{1}, \sigma_{2}\right)=(0.03,0.03),(0.05,0.05),(0.1,0.1)$ and $(0.3$, $0.3)$. It is shown that the power of performance is an increasing function of contamination level provided that the standard deviation, and decreasing function. The power of performance depends on the level of contamination, $\tau$, where the proposed statistic is able to detect almost all contamination points for $\tau>0.3$.

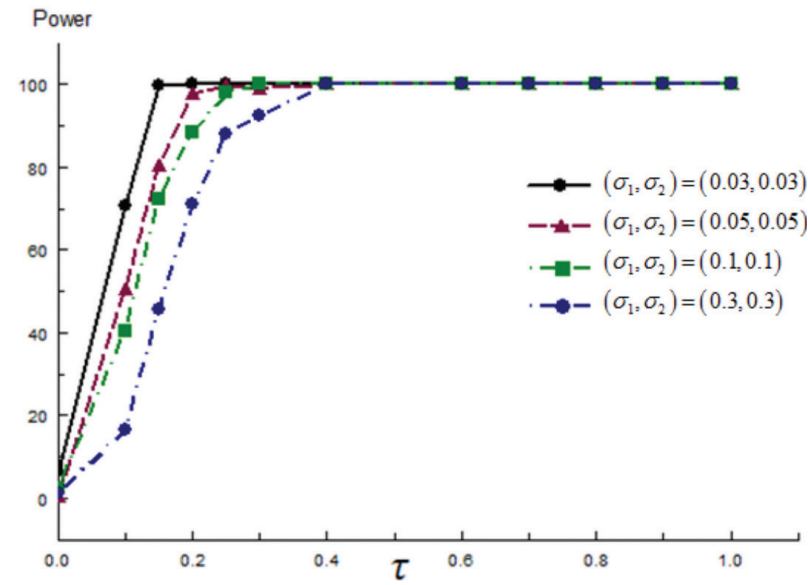

FIGURE 1. Power performance for DFFITC statistic for $n=100$

Figure 2 shows the performance of DFFITc statistic for and different sample sizes, $n$. For DFFITC statistic, the power of performance is an increasing function of sample 
size $n$. It is also clear and show good performance if the contaminated level is greater than $0.3,(\tau \geq 0.3)$. Similar results were obtained for fixed values of $\left(\sigma_{1}, \sigma_{2}\right)=(0.1,0.1)$ and different sample sizes $n$ as shown in Figure 3. These results are supported by Alkasadi et al. (2018) and Ibrahim et al. (2013).

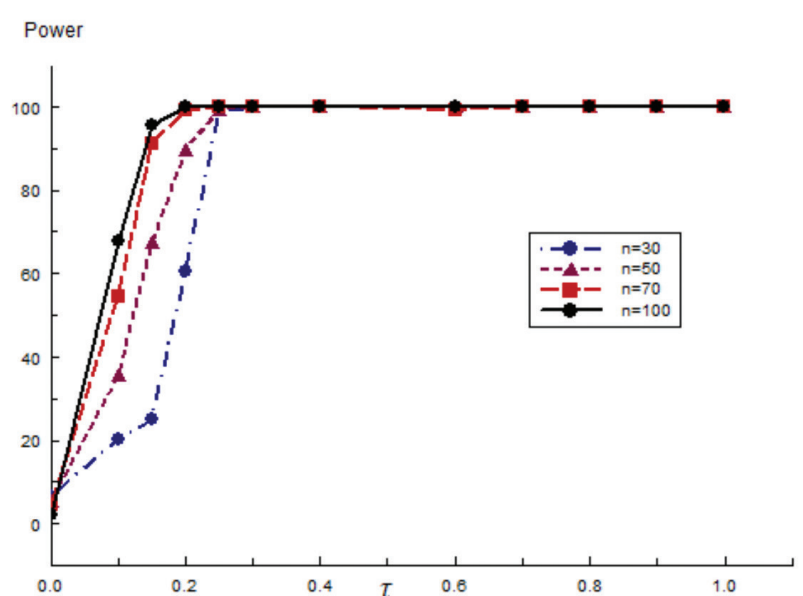

FIGURE 2. Power performance for DFFITc statistic for $\left(\sigma_{1}, \sigma_{2}\right)=(0.05,0.05)$

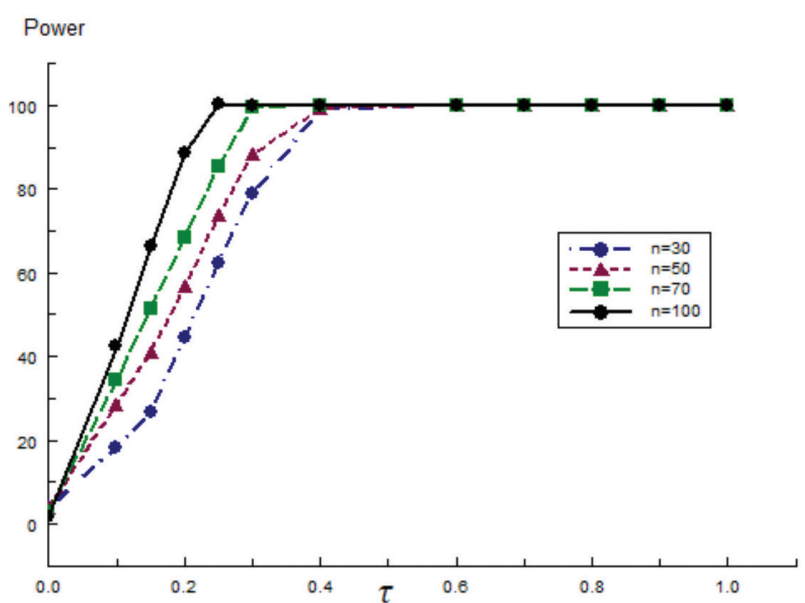

FIGURE 3. Power performance for DFFITC statistic for $\left(\sigma_{1}, \sigma_{2}\right)=(0.1,0.1)$

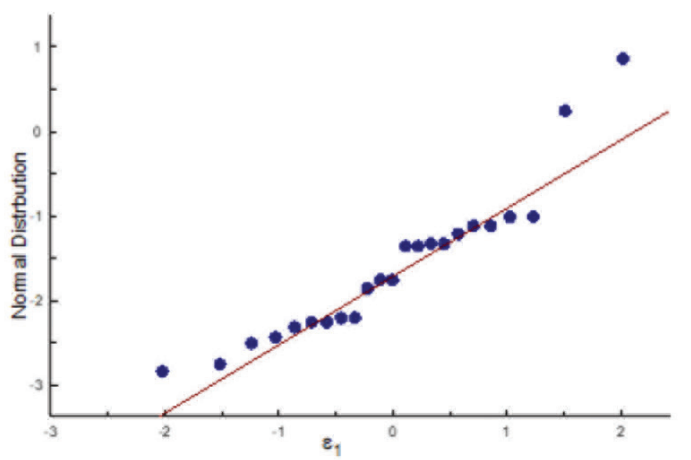

\section{PRACTICAL EXAMPLE: MULTIVARIATE EYE DATA}

The multivariate eye data consist of 23 observations of glaucoma patients recorded using Optical Coherence Tomography at the University Malaya Medical Centre, Malaysia for three angles $v, u_{1} u_{2}$ (Alkasadi et al. 2018 \& Ibrahim 2013).

Thus, the MCRM is used to fit the multivariate eye data. The least squares parameter estimates of MCRM are given as follow;

$$
\begin{aligned}
& \hat{A}_{0}=-1.076, \hat{A}_{1}=7.0890, \hat{B}_{1}=-11.6852, \hat{C}_{1}=2.9691, \\
& \hat{D}_{1}=-1.4526, \hat{E}_{0}=3.1246, \hat{E}_{1}=-9.9634, \hat{F}_{1}=16.5369, \\
& \hat{G}_{1}=-4.2270, \hat{H}_{1}=2.2351, \hat{\sigma}_{1}=0.17 \text { and } \hat{\sigma}_{2}=0.14 .
\end{aligned}
$$

The MCRM of multivariate eye data respect to $\hat{g}_{1}\left(u_{1}, u_{2}\right)$ and $\hat{g}_{2}\left(u_{1}, u_{2}\right)$ are given by

$$
\begin{aligned}
\hat{g}_{1}\left(u_{1}, u_{2}\right)= & -1.076+7.0890 \cos u_{1} \cos u_{2}-11.6852 \\
& \cos u_{1} \sin u_{2}+2.9691 \sin u_{1} \cos u_{2}-1.4526 \\
& \sin u_{1} \sin u_{2} \\
\hat{g}_{2}\left(u_{1}, u_{2}\right)= & 3.1246-9.9634 \cos u_{1} \cos u_{2}+16.5369 \\
& \cos u_{1} \sin u_{2}-4.2270 \sin u_{1} \cos u_{2}+2.2351 \\
& \sin u_{1} \sin u_{2}
\end{aligned}
$$

Figure 4 illustrates the Q-Q plot for residuals. The corresponding plot of $\varepsilon_{1}$ shows that almost all points are adjacent to the straight line excluding only two points positioned at the upper right of the plot (observations number 1 and 23). Meanwhile, plot of $\varepsilon_{2}$ also showed that almost all points are adjacent to the straight line, excluding only one point positioned at the upper right of the plot (observation number 1).

By applying DFFITC statistic on the regression model of multivariate eye data in order to detect any possible outliers, we obtain the cut-off point equals to 0.08134 . Figure 5 shows only one observation is above the specific cut-off point, which is observation number one.

Table 2 presents the effect of removing of detected outlier on the parameters estimates. Upon excluding observation 1 from the multivariate eye data set changes the value of the parameters estimates where the standard

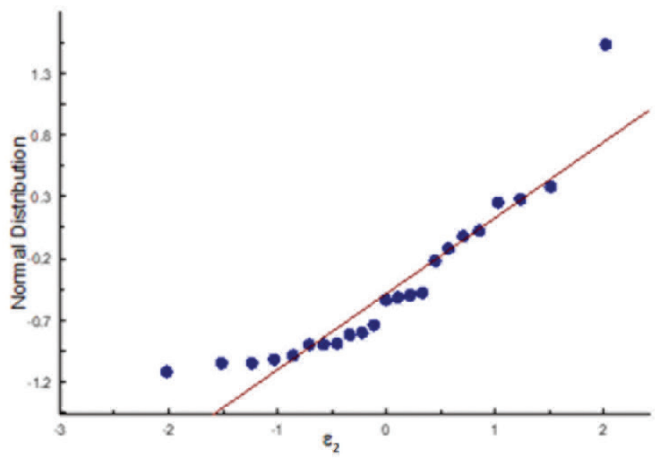

FIGURE 4. The Q-Q plot for residuals of fitted MCRM for eye data $(n=23)$ 


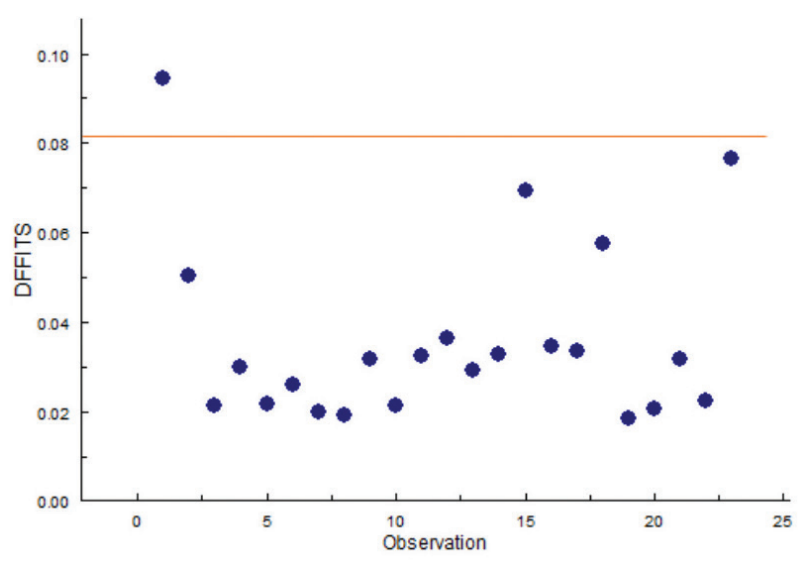

FIGURE 5 . The values of DFFITc statistic to the multivariate eye data $(n=23)$

error becomes smaller for all parameters estimate. The concentration parameter increases from 0.96 to 0.992 upon deleting observation number one. Figure 6 plot shows that the quantiles are close to the straight line indicating the best fit for the data.

\section{CONCLUSION}

Anew outlierdetection statistic formultiple circularmodel was proposed by extending the DFFITc statistic from the multiple linear regression model and based on row deletion approach.

The cut-off points are obtained and the power of performance were investigated via simulation study. The statistic showed a very good performance in identifying prospective outlier in the MCRM even for lower level of contamination. The application of the proposed statistics on the multivariate eye data revealed one outlier which is consistent to the findings of Alkasadi et al. (2018, 2016).

\section{ACKNOWLEDGEMENTS}

Authors are most grateful and would like to thank the reviewers for their valuable suggestions, which led to an improvement of the article. The authors are also gratefully

TABLE 2. MCRM parameters estimates for full and reduced multivariate eye data

\begin{tabular}{ccccc}
\hline $\begin{array}{c}\text { Parameter } \\
\text { estimates }\end{array}$ & $\begin{array}{c}\text { Full } \\
\text { data }\end{array}$ & $\begin{array}{c}\text { Standard } \\
\text { error }\end{array}$ & $\begin{array}{c}\text { Reduced data } \\
\text { (case 1 deleted) }\end{array}$ & $\begin{array}{c}\text { Standard } \\
\text { error }\end{array}$ \\
\hline$\hat{A}_{0}$ & -1.071 & $(0.037)$ & -1.097 & $(0.036)$ \\
$\hat{A}_{1}$ & 7.089 & $(0.050)$ & 7.244 & $(0.042)$ \\
$\hat{B}_{1}$ & -11.685 & $(0.053)$ & -12.192 & $(0.052)$ \\
$\hat{C}_{1}$ & 2.969 & $(0.027)$ & 3.021 & $(0.025)$ \\
$\hat{D}_{1}$ & -1.452 & $(0.036)$ & -1.471 & $(0.036)$ \\
$\hat{E}_{0}$ & 3.124 & $(0.039)$ & 3.176 & $(0.030)$ \\
$\hat{E}_{1}$ & -9.963 & $(0.058)$ & -9.954 & $(0.042)$ \\
$\hat{F}_{1}$ & 10.536 & $(0.037)$ & 10.537 & $(0.029)$ \\
$\hat{G}_{1}$ & -4.227 & $(0.047)$ & -4.052 & $(0.035)$ \\
$\hat{H}_{1}$ & 2.235 & $(0.036)$ & 2.026 & $(0.026)$ \\
$\hat{\sigma}_{1}$ & 0.136 & $(0.285)$ & 0.120 & $(0.110)$ \\
$\hat{\sigma}_{2}$ & 0.115 & $(0.230)$ & 0.112 & $(0.133)$ \\
$\hat{\rho}$ & 0.96 & - & 0.992 & - \\
\hline
\end{tabular}
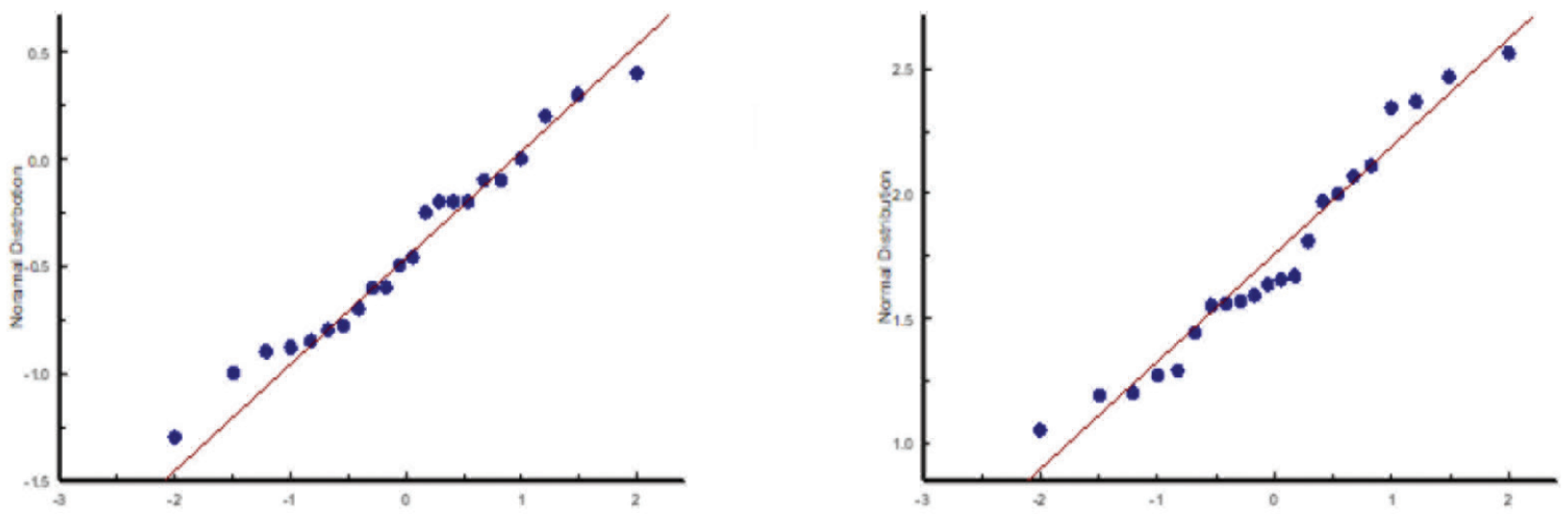

FIGURE 6. Q-Q plot of circular residuals after removing observation number $1(n=22)$ 
acknowledge the financial support from the Ministry of Higher Education, Malaysia (FRGS/1/2019/STG06/ UNIMP/02/7).

\section{REFERENCES}

Abuzaid, A.H., Hussin, A.G. \& Mohamed, I.B. 2013. Detection of outliers in simple circular regression models using the mean circular error statistic. Journal of Statistical Computation and Simulation 83(2): 269-277.

Abuzaid, A., Mohamed, I., Hussin, A.G. \& Rambli, A. 2011. COVRATIO statistic for simple circular regression model. Chiang Mai International Journal of Science and Technology 38(3): 321-330.

Abuzaid, A.H., Mohamed, I.B. \& Hussin, A.G. 2009. A new test of discordancy in circular data. Communications in StatisticsSimulation and Computation 38(4): 682-691.

Alkasadi, N.A., Abuzaid, A.H., Ibrahim, S. \& Yusoff, M.I. 2018. Outliers detection in multiple circular regression models via DFBETAc statistic. International Journal of Applied Engineering Research 13(11): 9083-9090.

Alkasadi, N.A., Ibrahim, S., Ramli, M.F. \& Yusoff, M.I. 2016. A comparative study of outlier detection procedures in multiple circular regression. AIP Conference Proceedings 1775(1): 030032.

Ampanthong, P. \& Suwattee, P. 2009. A comparative study of outlier detection procedures in multiple linear regression. In Proceedings of the International MultiConference of Engineers and Computer Scientists Volume 1.

Beckman, R.J. \& Cook, R.D. 1983. Outlier......... s. Technometrics 25(2): 119-149.

Belsley, D.A., Kuh, E. \& Welsch, R.E. 1980. Regression Diagnostic: Identifying Influential Data and Sources of Collinearity. New York: John Wiley \& Sons.

Cousineau, D. \& Chartier, S. 2010. Outliers detection and treatment: A review. International Journal of Psychological Research 3(1): 58-67.

Hussin, A.G., Abuzaid, A.H., Ibrahim, A.I.N. \& Rambli, A. 2013. Detection of outliers in the complex linear regression model. Sains Malaysiana 42(6): 869-874.

Ibrahim, S. 2013. Some Outlier Problems in a Circular Regression Model. PhD Thesis, University of Malaya (Unpublished).

Ibrahim, S., Rambli, A., Hussin, A.G. \& Mohamed, I. 2013. Outlier detection in a circular regression model using COVRATIO statistic. Communications in StatisticsSimulation and Computation 42(10): 2272-2280.

Peña, D. 1990. Influential observations in time series. Journal of Business \& Economic Statistics 8(2): 235-241.

Rambli, A., Yunus, R.M., Mohamed, I. \& Hussin, A.G. 2015. Outlier detection in a circular regression model. Sains Malaysiana 44(7): 1027-1032.

Rambli, A., Ibrahim, S., Abdullah, M.I., Mohamed, I. \& Hussin, A.G. 2012. On discordance test for the wrapped normal data. Sains Malaysiana 41(6): 769-778.
Rousseeuw, P.J. \& Leroy, A.M. 2005. Robust Regression and Outlier Detection. New York: John Wiley \& Sons.

Wong, C. 1992. Diagnostic and Influence Measures in Linear Regression. PhD Thesis. Simon Fraser University (Unpublished).

Zakaria, A., Howard, N.K. \& Nkansah, B.K. 2014. On the detection of influential outliers in linear regression analysis. American Journal of Theoretical and Applied Statistics 3(4): 100-106.

Najla Ahmed Alkasadi \& Safwati Ibrahim*

Institute of Engineering Mathematics

Universiti Malaysia Perlis

Pauh Putra Main Campus

02600 Arau, Perlis Indera Kayangan

Malaysia

Ali H.M. Abuzaid

Department of Mathematics

Faculty of Science

Al-Azhar University-Gaza

Palestine

Mohd Irwan Yusoff

Center for Diploma Studies

S2-L1-26, Kampus Uniciti Sungai Chuchuh

Universiti Malaysia Perlis

02100 Padang Besar (U), Perlis Indera Kayangan

Malaysia

Hashibah Hamid

School of Quantitative Sciences

College of Arts \& Sciences

Universiti Utara Malaysia (UUM)

06010 UUM Sintok, Kedah Darul Aman

Malaysia

Leow Wai Zhe \& Amelia Bt Abd Razak

School of Electrical System Engineering

Universiti Malaysia Perlis

Pauh Putra Main Campus

02600 Arau, Perlis Indera Kayangan

Malaysia

*Corresponding author; email: isafwati@gmail.com

Received: 16 October 2018

Accepted: 3 May 2019 